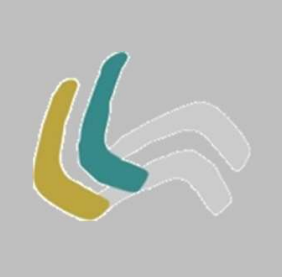

\title{
A CIDADE SURREAL NA POÉTICA AFRO-BRASILEIRA CONTEMPORÂNEA: UM OLHAR À PRODUÇÃO DE CRIOLO
}

\begin{abstract}
THE SURREAL CITY IN THE CONTEMPORARY AFROBRAZILIAN POETIC: A LOOK AT CRIOLO'S PRODUCTION
\end{abstract}

\author{
Lucas Toledo de Andrade ${ }^{1}$ \\ Universidade Pitágoras Unopar
}

\begin{abstract}
Resumo: Este artigo pretende tratar da produção do músico e compositor Criolo como parte da poética afro-brasileira contemporânea, a partir da leitura de algumas composições e dos recursos formais trazidos por elas. O foco deste trabalho está na percepção do modo como a cidade é representada nas letras e ritmos propostos pelo artista e da forma como essa representação possibilita uma percepção expandida da existência, permitindo a reflexão sobre o discurso historiográfico brasileiro e a condição do negro no país, o que se relaciona diretamente com o potencial crítico e revolucionário presente na imagem surrealista.
\end{abstract}

Palavras-Chave: Criolo; Poética afro-brasileira; Imagem surrealista.

1 Endereço eletrônico: ltoledodeandrade@gmail.com. 
Abstract: This article intends to treat of the production of musician and composer Criolo as part contemporary afro-Brazilian poetic, from of reading of some compositions and the formal resources brought by them. The focus of this essay is on the perception of how the city is represented in lyrics and rhythms proposed by the artist and how this representation enables an expanded perception, allowing reflection about Brazilian historiographical discourse and the black condition in the country, which is related to the critical and revolutionary potential of surrealist image.

Keywords: Criolo; Afro-Brazilian poetic; Surreal image.

\section{CONSIDERAÇÕES INICIAIS}

A produção literária afro-brasileira é marcada por múltiplos significados e representações, sendo um campo no qual os discursos artísticos relacionam-se diretamente com a história, com a política, com a sociologia, com a filosofia, com a antropologia e com diversas outras áreas do saber, pois produzir arte vinculada às questões étnicas em um país como o Brasil é sempre construir um discurso que aponta para os mais diversos caminhos, nos quais o formal artístico imbrica-se a todo o momento com o contexto histórico, social e político.

Além disso, ao tratarmos das produções afro-brasileiras falamos, segundo Duarte (2010), de um campo de estudo marcado pela ideia de elasticidade, o que nos possibilita dizer que as mais diversas manifestações artísticas podem abrigarse em torno desse conceito ampliando-o e o problematizando:

Nesse contexto, vejo no conceito de literatura afro-brasileira uma formulação mais elástica (e mais produtiva), a abarcar tanto a assunção explícita de um sujeito étnico - que se faz presente numa série que vai de Luiz Gama a Cuti, passando pelo "negro ou mulato, como queiram", de Lima Barreto -, quanto o dissimulado lugar de enunciação que abriga Caldas Barbosa, Machado, Firmina, Cruz e Sousa, Patrocínio, Paula Brito, Gonçalves Crespo e tantos mais. Por isso mesmo, inscreve-se como um operador capacitado a abarcar melhor, por sua amplitude necessariamente compósita, as várias tendências existentes na demarcação discursiva do campo identitário afrodescendente em sua expressão literária. (DUARTE, 2010, p. 121)

As discussões em relação à ideia de elasticidade da literatura afrobrasileira tornam-se ainda mais necessárias no cenário contemporâneo, visto que 
as linguagens das mídias, das tecnologias, da música, das performances artísticas, do cinema, da televisão e das redes sociais cada vez mais dialogam com o literário, fazendo-se, muitas vezes, como elemento estético representativo em produções literárias da atualidade.

Nesse sentido, podemos dizer que as fronteiras entre a literatura e as outras linguagens encontram-se borradas e diluídas e isso leva à ampliação da própria percepção do que é e do modo como se faz literatura de modo geral. Tratando, especificamente, da literatura afro-brasileira, como parte da "tradição fraturada" da literatura brasileira (PEREIRA, 1995), essa diluição de fronteiras pode funcionar como um interessante recurso para a construção de um discurso artístico que se faça nos "entre-lugares" existentes entre a cultura dominadora e a cultura dominada, por meio da realização de uma negociação cultural (BHABA, 2013), que pode permitir ao negro driblar o poder opressor e constituir-se como dono de uma fala própria, que reflita e reelabore a sua condição em um país racista como o Brasil.

Sendo assim, este artigo buscará pensar a produção do músico e compositor Criolo como parte da poética afro-brasileira contemporânea, na medida em que o artista em questão valendo-se do ponto de vista de um homem negro e da periferia de São Paulo, especificamente do Grajaú, busca revisar a história brasileira e repensar artisticamente e politicamente a situação do indivíduo negro e periférico no Brasil de hoje.

É necessário dizer que a produção de Criolo é bastante plural, uma vez que em seus álbuns ${ }^{2}$ e singles ${ }^{3}$, percebemos o modo como os diversos ritmos misturam-se, por meio de versos entrecortados pelas mais variadas referências, o que nos revela que a fragmentação é uma marca formal bastante perceptível nas canções do músico, sejam por meio do texto, recheado de bricolagens e

2 Ainda há tempo (2006); Nó na orelha (2011); Convoque seu buda (2014); Ainda há tempo (2016) e Espiral de ilusão (2017).

3 “Boca de Lobo" (2018); “Etérea” (2019). 
ligações de imagens disparatadas, como por meio dos ritmos que remetem ao rap, ao afrobeat, ao reggae, aos tambores usados nos ritos umbandistas e do candomblé e até mesmo às batidas da música eletrônica.

A fragmentação formal existente na poética de Criolo dá-se, quase sempre, no espaço da metrópole, que também aparece para o receptor, por meio de imagens recortadas e estilhaços de ideias. Dentro dessa perspectiva, podemos falar que a cidade em Criolo é um ser vivo, um texto aberto (BARTHES, 1992), "um labirinto místico" (CRIOLO, 2011) em que as diferentes mitologias se encontram e em que os diferentes tempos se chocam, implodindo no interior do próprio texto, o que leva à criação de imagens novas e, consequentemente, a uma outra percepção da existência.

A cidade é o lócus escolhido para a reflexão crítica do eu lírico, criado pelo poeta, acerca do Brasil, da condição do negro e da vida do homem de periferia. Todavia, a percepção desse eu lírico não se dá por meio de uma subjetividade caótica, que foge daquilo que se chama convencionalmente de realismo.

A urbe de Criolo não é homogênea, nem linear, não é do presente, do passado, ou do futuro e, além disso, não é habitada unicamente por seres humanos, mas, em muitos momentos, por seres mitológicos e por elementos inanimados que se enchem de vida. O espaço urbano criado dessa forma, juntamente dos ritmos utilizados, trazem à tona imagens que despertam a atenção do receptor, na medida em que expandem a apreensão da realidade, questionando lugares-comuns e os estereótipos, convidando os sujeitos a observarem o mundo por uma outra lógica.

Desse modo, pretende-se pensar a representação da cidade na poética de Criolo, a partir do surrealismo, bem como no modo como os diversos elementos poéticos dessa vanguarda contribuem para um olhar crítico e político para o tempo presente. 
É válido dizer ainda que a percepção surrealista da cidade em Criolo ligase diretamente, nesse caso, à reflexão sobre a história e a condição do negro na sociedade brasileria, visto que as diversas temporalidades implodem nas composições do artista, possibilitando um olhar para a história que foge de uma concepção de tempo linear e burguesa. Para essa discussão, levar-se-á em consideração as ideias de Walter Benjamin no famoso ensaio "Sobre o conceito da história", publicado originalmente em 1940, e também as reflexões trazidas por Jeanne Marie Gagnebin (2018), a partir do já citado texto benjaminiano.

Essas reflexões terão também como base o potencial artístico revolucionário presente na imagem poética surrealista que pensada a partir da produção do artista negro no contexto da literatura afro-brasileira contemporânea oferece a possibilidade de realização de uma discussão política e crítica sobre as vivências afro-brasileiras ao longo da história e do modo como elas podem ser tratadas na arte do presente.

\section{A CIDADE SURREAL EM CRIOLO}

Criolo é o nome artístico de Kleber Cavalgante Gomes, artista paulistano, que cresceu no Grajaú, periferia de São Paulo, e traz à tona em suas composições um olhar bastante crítico e apurado à realidade do homem negro brasileiro.

É importante dizer que o Criolo, por meio da escolha do próprio nome artístico, já busca a subversão de estereótipos lançados ao negro ao longo da história brasileira, uma vez que a ideia de ser "crioulo" no nosso país sempre esteve ligada a uma conotação pejorativa e de menosprezo (SILVA; ROSEMBERG, 2012), algo que é destruído, por meio de uma ressignificação positiva, uma vez que o ser Criolo, com letras maiúsculas, é ser alguém ativo diante do seu próprio destino, alguém capaz de questionar a sociedade, alguém que possui orgulho de ser quem é, algo que se vê nos versos de "Sucrilhos" 
(2011), quando o eu lírico diz "eu tenho orgulho da minha cor/ do meu cabelo e do meu nariz" (CRIOLO, 2011), alguém capaz de refletir sobre sua própria condição e, consequentemente, modificá-la.

O artista em “Boca de Lobo", lançado em setembro de 2018, diz: “Está por vir, um louco está por vir, / Shinigami, deus da morte, / um louco está por vir" (CRIOLO, 2018), revelando o clima de apreensão e medo que invadia o Brasil às vésperas da eleição presidencial daquele ano. O clipe e a composição revelam o cenário de caos que tomou as ruas da cidade em um país guiado pelo ódio ao preto, ao pobre, ao diferente, algo muito atual, apesar de muito antigo e característico do Brasil de hoje e de sempre.

A cidade em Criolo se faz sempre como um texto aberto (BARTHES, 1992) e em ruínas. Ela é o espaço do deslocamento infindável das identidades múltiplas que compõem o seu cenário. Na urbe de Criolo residem os mais diversos universos, habitá-la é estar sempre em constante viagem, em constante processo de descoberta, no qual o subjetivo e o objetivo se encontram e deixam de ser pares de oposição, para se complementarem.

Não é por acaso que "Boca de Lobo" (2018) se inicia com a citação de um trecho do poema "Câmara de Ecos", de Waly Salomão (2007), que diz "Agora, entre meu ser e o ser alheio/ A linha de fronteira se rompeu", já apontando para o arruinamento de qualquer fronteira entre a cidade e o homem, que não é mais o eu do antropocentrismo, com sua identidade fixa e seu poder sobre as coisas, mas só mais um objeto em meio ao caos que toma conta do mundo, que é nos dizeres de Paz (1994, p. 206, tradução nossa) a "gigantesca máquina que gira no vazio, alimentando-se sem cessar de seus detritos".

A cidade no videoclipe de "Boca de Lobo" (2018) é tomada por animais gigantescos que destroem prédios e assustam os homens, e, além disso, por sangue, dinheiro, cocaína, risos da elite e gritos de meninos de rua, o que a aproxima da cidade de “Chuva ácida" (2006; 2016), por exemplo, que é invadida 
por animais mutantes que devoram os indivíduos "caranguejo gigante decepando seus corpos/ Aniquilar suas famílias, jogá-las aos corvos/ Garças bizarras movidas a óleo, sem dó e sem dor/ Bicando seus olhos"' (CRIOLO, 2006; 2016) sendo habitada ainda por homens de negócios que são sócios do diabo “o demônio é meu sócio" (CRIOLO, 2006; 2016).

Notamos que o espaço urbano que emerge das composições do músico, algumas feitas em parceria, é sempre habitado por elementos estranhos a ele e por referências a universos distantes que nem sempre podem ser observados a partir de um olhar superficial às ruas de uma cidade qualquer, formando aquilo que, segundo Breton, a partir de Reverdy, é a imagem surrealista:

A imagem é uma criação pura do espírito. Ela não pode nascer da comparação, mas da aproximação de duas realidades mais ou menos remotas. Quanto mais longínquas e justas forem as afinidades de duas realidades próximas, tanto mais forte será a imagem - mais poder emotivo e realidade poética ela possuirá... etc. (REVERDY, 1918 apud BRETON, 1985, p. 187)

O espaço urbano forma nas composições de Criolo a imagem com a força poética e poder emotivo capazes de possibilitar ao receptor uma percepção da realidade a partir de uma outra perspectiva, que vai para muito além das diversas formas de binarismos provenientes do senso comum e da lógica que alimenta a cultura cristã.

Como exemplo dessa criação de uma imagem urbana que se aproxima da elaboração imagética surrealista é possível citar também a cidade de "Convoque seu Buda" (2014) e "Fio de Prumo (Padê Onã)" (2014) ambas habitadas por deuses mitológicos dos mais diversos universos, em especial, os da mitologia africana, que andam em meio ao caos da urbe. É o caso do Exu, de "Fio de Prumo (Padê Onã)" (2014), o deus que abre os caminhos: “Laroyê Bará [...] abra caminho tranquilo pra eu passar" (CRIOLO, 2014), em meio a uma cidade construída no entrecruzamento de tempos, lugares e referências variadas: 
Muros de concreto infeto

De pedra, cal, cimento e dejeto

Aponta pra cabeça, Ori

A cidade um cronista, Ogi

E a dobra do dorso do operário na rua

Labirinto, fauno, a sombra, a luz da lua

Aço, peito, flecha, caminho

Magma, lava, inveja, vizinho

Posto de saúde dos anos 80

A.S, benzetacil, cibalena

Vida real dessa filosofia

Máquinas comem você, meio dia

(GERMANO; CRIOLO, 2014)

O trecho citado anuncia a destruição da história linear e progressista, escrita sempre pela voz do dominador e que se vale de uma concepção homogênea e vazia de tempo, na medida em que traz a referência a diversas temporalidades, revelando o modo como o passado e até mesmo o futuro coexistem no agora. Nesse sentido, o presente é o lugar de entrecruzamento de todos os tempos.

Vemos a cidade em fragmentos: o concreto, a pedra, a cal, Ori, Ogi, a figura do operário, o labirinto, o fauno, a luz da lua, a inveja, os anos 80, os medicamentos populares e as máquinas engolindo um homem preso ao tempo sempre veloz do capitalismo.

Notamos a total quebra de fronteiras entre o concreto, o abstrato, o real e o ficcional. A cidade concreta representada pela cal, pela pedra, pelos muros é também uma cidade abstrata vista pelos olhos de Ogi (rapper, cronista, beatmaker e grafiteiro de São Paulo, conhecido pelo álbum de rap Crônicas da cidade cinza, de 2011) e é ainda um espaço em que o mitológico habita, basta notar a referência ao fauno, um ser mitológico, e a elementos próprios desse mito, como, por exemplo, a luz da lua. Esses elementos podem ser lidos também como uma referência ao filme de Guillermo Del Toro, O labirinto do Fauno (2006), no qual os 
limites entre fantasia e realidade são nebulosos e até certo ponto inexistentes, assim como no próprio rap-canção de Criolo.

Percebemos também a referência à mitologia iorubá, algo muito comum em outras canções do músico, por meio do “ori”, menção iorubana à cabeça física, mas também símbolo da "cabeça interior" - a intuição. Além disso, "ori" pode ser visto como o orixá pessoal de cada indivíduo, que acompanha o ser do nascimento à morte, se fazendo presente em todos os tempos da existência do homem. O "ori" pode representar, então, aquilo que simboliza mitologicamente a existência de todos os tempos - passado, presente e futuro - no agora.

Não é por acaso que o posto de saúde dos anos 80, junto dos remédios populares, indicados aos pacientes diante de qualquer diagnóstico, que vai da dor de cabeça até uma doença mais grave, não funcionam só como uma crítica ao péssimo atendimento médico recebido pelos negros e pobres ainda nos dias de hoje, visto que as precárias condições da saúde pública dos anos 80 coexistem na contemporaneidade, mas também como uma revelação de que o passado para as minorias nunca, de fato, passou, ideia presente no ensaio benjaminiano acerca do conceito da história (2012), o que nos permite mencionar um trecho da canção “Esquiva da esgrima” (2014) em que se diz: “Cada cassetete é um chicote para um tronco", exibindo que as formas de opressão só se atualizam e se modificam, mas nunca deixam de existir, pois o chicote que açoitava o escravizado transformou-se no cassetete que a polícia usa contra os negros em nossos tempos.

Benjamin em seu já citado texto a respeito do conceito da história mostra que “a tradição dos oprimidos nos ensina que o 'estado de exceção' em que vivemos é na verdade a regra geral" (BENJAMIN, 2012, p. 245). Sendo assim, o desrespeito aos direitos humanos, a censura, a violência e a opressão são na tradição histórica dos oprimidos uma regra e não uma exceção de fato, o que faz com que o cassetete se transforme em chicote na contemporaneidade, fazendo 
com que as dores vivenciadas no processo de escravização se mantenha viva e pungente em nossos tempos.

Criolo consegue, por meio do uso formal do espaço urbano e da fragmentação do tempo, valendo-se assim da imagem surrealista, manter acesa no presente as dores históricas do passado, o que revela a necessidade de se discutir criticamente sobre a escravidão, sobre o racismo e sobre a condição do negro em um país que olha passivamente para a sua história e aceita, na maioria das vezes, o ponto de vista das elites, que é quem mantêm o poder sobre o discurso historiográfico oficial, que na produção do artista é quebrado pelo olhar e pela voz de um homem pertencente a uma minoria.

O modo como Criolo trata o tempo em suas composições, vale aqui mencionar também os ritmos usados no seu rap-canção, que misturam as batidas secas e características do rap tradicional com os tambores dos ritos dos africanos e afro-brasileiros, o que já mostra uma junção do ancestral e do contemporâneo na mesma fatia de temporalidade, se aproxima bastante de uma concepção benjaminiana de tempo.

É interessante notar que o ancestral vem à tona, muitas vezes nas canções do músico, por meio da colagem de cantigas usadas em rituais africanos, como é o caso de "Ogum adjo, ê mariô (Okunlakaiê)/ Ogum adjo, ê mariô (Okunlakaiê)" (CRIOLO; DINNUCI, 2011), um antigo cântico da nação Ketu, que é entoado no início de "Mariô" (2011). Esse canto faz referência direta a Ogum, o orixá da guerra, da agricultura e da tecnologia, que é chamado, nesses versos, para reanimar os seus filhos, utilizando da força do mariô ${ }^{4}$.

Os versos em iorubá evidenciam a resistência linguística em relação à fala dominante. Em 'Mariô' (2001) misturam-se as rimas entrecortadas do rap do músico, que revelam a força da cultura periférica e dos próprios sujeitos

\footnotetext{
4 Folha de dendezeiro usada nas vestes de Ogum, que é também colocada nos assentamentos a esse orixá. Além disso, essa folha pode ser vista na porta de terreiros com a função de espantar as energias negativas e os espíritos perturbadores.
} 
periféricos, que nessa canção são considerados guerreiros, referindo-se às ideias em torno do arquétipo de Ogum.

Percebemos, dessa forma, o modo como as mais diversas fatias temporais coexistem e dialogam nas canções de Criolo, corroborando a própria ideia da imagem poética surrealista e da concepção de tempo benjaminana. Em "Mariô" (2011) tem-se a ancestralidade da língua iorubá, ao lado das gírias dos "quinhentos mil manos", da realidade contemporânea das periferias das grandes cidades, do discurso agressivo daqueles que cansaram de ser oprimidos e que anunciam ao dominador "Tenho pra você uma caixa de lama/ Um lençol de fel pra forrar a sua cama/ Na força do verso a rima que espanca/ A hipocrisia doce que alicia nossas crianças" (CRIOLO, 2011), revelando o modo como o olhar passivo transforma-se em olhar político, fazendo com que o sujeito subjugado pelas relações de poder ganhe voz, tornando-se capaz, inclusive, de abalar as estruturas do discurso do outro.

Esse abalo nas estruturas do discurso construído pelo poder dominador vem por meio da imagem poética surrealista, que formada pelas mais disparatadas figuras, destroem a contemplação passiva da existência, implodindo as fronteiras temporais e reescrevendo, dessa forma, um outro discurso que questiona a linearidade da história oficial, sendo capaz de reacender o passado no presente.

Dessa forma, é válido trazer a interpretação de Jeanne Marie Gagnebin acerca da nona tese de Walter Benjamin, que trata da famosa figura do anjo de Paul Klee:

Essa alegoria nos ensina duas coisas. Primeiramente, a história também é algo que poderia ter sido completamente diferente; o que era possível e não se realizou, não por fraqueza ou incapacidade, como pretenderia um pragmatismo otimista, mas porque a dominação impôs-se. As ruínas da história acusam e continuam a crescer. O historiador não pode, entretanto, como o anjo da alegoria, deter-se para contemplar o espetáculo, mesmo que quisesse "demorar-se um pouco". Tal contemplação faria certamente justiça 
à "tradição dos oprimidos", como a chama Benjamin, e criaria outra memória que não a dos livros e da história. No entanto, e aí reside o segundo aspecto da alegoria, o anjo da história é empurrado à frente pelo vento do Paraíso; deve continuar a avançar apesar de sua tristeza, necessidade que Benjamin denomina de "progresso", numa oposição irônica à doutrina socialdemocrata do progresso. O historiador materialista não pode, assim, contentar-se em colecionar fatos do passado, devendo também ser fiel à história do presente, porque é apenas através dela que o passado poderá talvez, algum dia, alcançar a sua libertação. (GAGNEBIN, 2018, p. 77)

Entendemos que apenas um olhar contemplativo ao passado das minorias, um olhar que entenda os sofrimentos, denuncie-os e os exiba não é suficiente para uma possível libertação, pois o presente também tem a sua própria história e seus aspectos específicos que precisam ser levados em consideração, pois é só no agora que é possível retomar o fio da história inacabada do passado para assim tecer a sua continuação:

A coincidência do passado com o presente não deve, para ele, liberar o indivíduo do jugo do tempo, mas operar uma espécie de condensação que permita ao presente reencontrar, reativar um aspecto do passado, e retomar, por assim dizer, o fio de uma história inacabada, para tecer-lhe a continuação. [...] Certo, o passado está consumado e é irrecuperável. Mas podemos, segundo Benjamin, ser-lhe fiel para além de seu fim, retomando em consideração suas exigências deixadas sem respostas. (GAGNEBIN, 2018, p. 71)

De certa forma, podemos dizer que as composições de Criolo buscam costurar no presente esse texto inacabado do passado, a partir do momento em que implode uma concepção de tempo linear, que se relaciona diretamente com a historiografia oficial, possibilitando com que as diversas temporalidades se exibam no agora, para que assim ele próprio consiga escrever a sua narrativa, a partir da experiência de homem negro da periferia no contexto do século XXI.

E a cidade não é apenas um texto solitário, mas o local em que um outro texto se escreve, fazendo-se como um montante de textos sem origem e sem destino, nos quais as mais disparatadas imagens se relacionam e os mais variados 
tempos se encontram, formando a imagem surreal. Para Benjamin, "nenhum rosto é tão surrealista quanto o verdadeiro rosto de uma cidade [...], mas somente a revolta desvenda o seu rosto surrealista" (BENJAMIN, 2012, p. 26) e a cidade de Criolo está sempre em revolta e em chamas.

Em Criolo, São Paulo deixa de ser a cidade observável objetivamente e torna-se outra metrópole, um “pequeno universo" (BENJAMIN, 2012, p. 27), onde tudo se relaciona e tem o mesmo aspecto, o que destrói hierarquias, devido à ideia de "objetivização do sujeito" e de "subjetivização do objeto" tratada por Octavio Paz (1994) ao observar a arte surrealista:

O objeto, instalado em sua realidade irrisória como um rei em um vulcão, prontamente troca de forma e se transforma em outra coisa. O olho que o olha o amolece como cera; a mão que o toca o modela como argila. O objeto se subjetiviza. [...] E assim se inicia uma vasta transformação da realidade. Filho do desejo, nasce o objeto surrealista: a reunião de montanhas é outra vez cenário de gigantes, as manchas na parede ganham vida, põem-se a voar e são um exército de aves que, com seus bicos terríveis rasgam o ventre da formosa acorrentada. [...] O caráter destrutivo dessas operações não é senão um primeiro passo; seu fim último é desnudar a realidade, despojá-la de suas aparências, para que mostre por fim seu verdadeiro rosto [...] Enquanto o mundo se torna maleável ao desejo, escapa as noções utilitárias e se entrega a subjetividade, o que ocorre com o sujeito? Aqui a subversão adquire uma tonalidade mais perigosa e radical. Se o objeto se subjetiviza, o eu se desagrega. [...] A sistemática destruição do eu - ou melhor dito: a objetivização do sujeito - se realiza [...] De alguma maneira em algum momento privilegiado, a realidade escondida se levanta de sua tumba de lugares comuns e coincide com o homem. Nesse momento paradisíaco, pela primeira e única vez, um instante e para sempre, somos de verdade. Ela e nós. Arrasado pelo humor e recriado pela imaginação, o mundo não se apresenta já como um "horizonte de utensílios" e sim como um campo magnético. (PAZ, 1994, p. 205-207, tradução nossa)

Nesse sentido, o indíviduo se torna só mais um elemento em meio a todas as outras coisas, assim como anuncia os versos de Wally Salomão, já citados e que abrem "Boca de Lobo" (2014), e os objetos deixam de ser apenas elementos concretos e sem vida para serem atravessados pela subjetividade humana. Assim sendo, homens, objetos e palavras compõem uma "realidade vivente" (PAZ, 
1994), deixando de ser meros utensílios do universo capitalista, o que, consequentemente, propicia uma transfiguração na percepção da realidade (WILLER, 1985).

Dessa forma, a cidade, suas ruas, sua arquitetura e os objetos que a compõem passam a ter aquilo que Benjamin chama, no texto intitulado " $\mathrm{O}$ surrealismo: o último instantâneo da inteligência europeia", publicado originalmente em 1929, de "energia revolucionária":

Para o surrealismo, nada pode ser mais revelador que a lista canônica desses objetos. Onde começar? Breton pode orgulhar-se de uma surpreendente descoberta. Foi o primeiro a ter pressentido as energias revolucionárias que transparecem no "antiquado", nas primeiras construções de ferro, nas primeiras fábricas, nas primeiras fotografias, nos objetos que começam a extinguir-se, nos pianos de cauda, nas roupas de mais de cinco anos, nos locais mundanos de reunião, quando a moda começa a abandoná-los. (BENJAMIN, 2012, p. 25)

Notamos, a partir de Benjamin, que os objetos no surrealismo ganham vida, pois estão dotados de sentidos e de força, uma vez que guardam o velho e o novo, a coexistência dos tempos, representando a modernidade e sua capacidade de produzir novidades que se tornam velhas em um piscar de olhos. Os objetos do surrealismo, nesse sentido, são ambíguos e abrigam contradições, pedindo, consequentemente, uma outra forma de se olhar para as coisas, na medida em que colocam em xeque uma visão contemplativa e passiva daquilo que nos rodeia.

Esses objetos entendidos como os "primeiros" de uma série de outros que virão com as transformações modernas guardam em si ruínas do novo e do velho, quase simultâneos em um tempo em que tudo é êfemero. É interessante notar que Benjamin fala sobre isso na segunda década do século $X X$, podemos dizer que em nossa época, no contexto de produção de Criolo, isso se potencializou de forma radical. 
Sendo assim, observar esses objetos transpassados pelas ruínas do tempo e pela subjetividade do olhar que os contempla é encontrar também a possibilidade de retomar, em certa medida, o fio da narrativa do passado no presente e, além disso, destruir binarismos e a linearidade da historiografia burguesa, o que se relaciona com a imagem surrealista:

Tudo indica a existência de um certo ponto do espírito, onde vida e morte, real e imaginário, passado futuro, o comunicável e o incomunicável, o alto e o baixo, cessam de ser percebidos como contraditórios. Ora, em vão se procura na atividade surrealista outro móvel que não a esperança de buscar esse ponto. Por isso se vê bem absurdo dar-lhe sentido unicamente destruidor, ou construtor: o ponto de que se cuida é a fortiori aquele onde a destruição e a construção não podem mais ser brandidas uma contra a outra. Claro está também que o surrealismo não tem interesse em valorizar tudo que se produz a seu lado a pretexto de arte, até de antiarte, de filosofia ou de antifilosofia, em uma palavra de tudo que não visa o aniquilamento do ser em um brilhante, interior e cego, que não seja nem a alma do gelo nem a do fogo. (BRETON, 1985, p. 98)

Entendemos pela citação do trecho do segundo manifesto do surrealismo, de 1930, que um dos objetivos do movimento é alcançar o ponto em que os opostos deixem de fazer sentido. A vanguarda, em última instância, não pretende só destruir, mas também construir, não é arte, assim como é, não faz filosofia, assim como faz. O surrealismo não pretende destruir uma contradição para criar outra, pelo contrário, visa o aniquilamento de qualquer contradição, para mostrar como tudo se relaciona, uma vez que só assim se chega a uma visão expandida e crítica da realidade, o que está por detrás da própria ideia de surrealidade.

A imagem surrealista ao buscar esse choque, por meio da apreensão do receptor de uma criação que liga elementos distantes e disparatados, chama a atenção para essa compreensão expandida do mundo e do homem, que pode ser um caminho para a transformação de todas as coisas e da troca do alienado olhar histórico para o crítico olhar político, que, segundo Benjamin, naquele contexto histórico específico, poderia oferecer as bases para a revolução. 


\section{CONSIDERAÇÕES FINAIS}

Após essas discussões, notamos que Criolo, em suas composições, ao ligar elementos disparatados e mostrar uma cidade em constante caos, cria a imagem surrealista e também pede ao receptor do seu conteúdo um olhar outro para o mundo que o rodeia, um olhar que vá para além do senso comum.

Criolo ao se esquivar do realismo nu e cru tão comum ao rap parece concordar com a ideia de que a convenção realista, de certa forma, ao tentar parecer natural e representativa da vida tal qual ela é acaba por "naturalizar a realidade social" fazendo "com que ela pareça tão inocente e imutável quanto a própria natureza", algo que nos mostra Eagleton (2006, p. 206), a partir de Barthes.

Sendo assim, o compositor ao usar a linguagem escrita, oral, rítmica e visual como forma de apresentar ao seu receptor um cenário aparentemente absurdo e irracional, mas que na verdade se baseia em outro tipo de racionalidade, que não é aquela alimentada pela ideologia dominante, não só crítica a sociedade em que vive, como propõe uma nova forma de ver o mundo, que consequentemente destrói, por meio da arte, toda a estrutura da "jaula de aço", expressão trazida por Löwy (2014) valendo-se de Weber, na qual o ser humano está encarcerado no mundo capitalista, o que revela o objetivo evidentemente político de sua produção.

Podemos assim retomar a sentença presente na letra de "Boca de Lobo" (2014) e usada para dar início a esse texto: “Está por vir/ o louco está por vir/ Shinigami, deus da morte, o louco está por vir" (2014). Criolo nesse trecho faz referência ao Brasil real e a possibilidade da loucura, da insanidade e do fascismo tomarem o poder, trazendo junto dela o sangue, a tortura e a morte já materializada nas ruas do país. Para simbolizar todo esse cenário caótico, ele traz 
uma referência à mitologia japonesa e à figura de Shinigami, o deus da morte e do suicídio, que revela o desespero e o medo de muitos diante do cenário que se desenha no futuro, aqui o real se une ao mitológico para pedir um olhar expandido à existência.

As composições de Criolo formalmente parecem nos informar de que um olhar binário e hierárquico pode, sem dúvida, nos levar à falência humana e, além disso, de que o eu só existe em relação ao outro, o que já põe abaixo as hierarquias que sustentam todo o pensamento ocidental, afinal não existe o superior ou inferior, mas as relações de complementaridade, uma vez que tudo está em relação de interdependência, sendo assim o rompimento da linha de fronteira entre o eu e o outro corresponde à queda desse olhar binário e a possibilidade de compreensão mais aguda do mundo, o que, de certa forma, está presente na imagem surrealista, a qual Criolo cria a partir de suas referências urbanas, periféricas e negras.

\section{REFERÊNCIAS}

BARTHES, Roland. S/Z. Tradução de Léa Novaes. Rio de Janeiro: Nova Fronteira, 1992. BENJAMIN, Walter. O surrealismo: o último instantâneo da inteligência europeia. In: Magia e técnica, arte e política: ensaios sobre literatura e história da cultura (Obras escolhidas I). Tradução de Sérgio Paulo Rouanet. São Paulo: Brasiliense, 2012, p. 21-36.

BENJAMIN, Walter. Sobre o conceito da história. In: Magia e técnica, arte e política: ensaios sobre literatura e história da cultura (Obras escolhidas I). Tradução de Sérgio Paulo Rouanet. São Paulo: Brasiliense, 2012, p. 241-252.

BHABHA, H. Introdução: locais da cultura. In: O local da cultura. Tradução de Myriam Ávila, Eliana Lourenço de Lima Reis, Gláucia Renate Gonçalves. Belo Horizonte: Editora UFMG, 2013, p. 19-46.

BRETON, André. Manifesto do Surrealismo. In: Manifestos do Surrealismo. Tradução de Luiz Forbes. São Paulo: Brasiliense, 1985, p. 31-82.

BRETON, André. Segundo Manifesto do Surrealismo. In: Manifestos do Surrealismo. Tradução de Luiz Forbes. São Paulo: Brasiliense, 1985, p. 89-166.

CRIOLO. Boca de lobo. 2018. Disponível em: <http://www.criolo.net/bocadelobo/>. Acesso em: 12 de out. 2018. 
CRIOLO. Chuva Ácida. In: Ainda há tempo. São Paulo: SkyBlue Music, 2006. 1 CD (3 min. 24 seg.).

CRIOLO. Chuva Ácida. In: Ainda há tempo. São Paulo: Oloko Records, 2016. 1 CD (3 $\min$.).

CRIOLO. Não existe amor em SP. In: Nó na orelha. São Paulo: Oloko Records, 2011. 1 CD (4 min. 41 seg.).

CRIOLO. Sucrilhos. In: Nó na orelha. São Paulo: Oloko Records, 2011. 1 CD. Faixa 8 (5 $\min .17$ seg.).

CRIOLO; DINUCCI, K. Mariô. In: CRIOLO. Nó na orelha. São Paulo: Oloko Records, 2011. 1 CD. Faixa 4 (5 min. 45 seg.).

CRIOLO; GANJAMAN, Daniel. Convoque seu buda. In: CRIOLO. Convoque seu buda. São Paulo: Oloko Records, 2014. CD. Faixa 1 (3 min. 51 seg.).

CRIOLO; GANJAMAN, Daniel; CABRAL, Marcelo. Esquiva da Esgrima. In: CRIOLO. Convoque seu buda. São Paulo: Oloko Records, 2014. 1 CD (4 min. 29 seg.).

DUARTE, Eduardo de Assis. Por um conceito de literatura afro-brasileira. In: Revista Terceira Margem, Rio de Janeiro, v. 14, n. 23, p. 113-138, jul/dez. 2010.

EAGLETON, Terry. O Pós-Estruturalismo. In: Teoria da literatura: uma introdução. Tradução de Waltensir Dutra. São Paulo: Martins Fontes, 2006, p. 191-226.

GAGNEBIN, Jeanne Marie. Walter Benjamin: cacos da história. Tradução de Sônia Salzstein. São Paulo: N-1 Edições, 2018.

GERMANO, Douglas; CRIOLO. Fio de prumo (Padê Onã). In: CRIOLO. Convoque seu buda. São Paulo: Oloko Records, 2014. 1 CD. Faixa 10 (4 min. 9 seg.).

LÖWY, Michael. A jaula de aço: Max Weber e o marxismo weberiano. Tradução de Mariana Echalar. São Paulo: Boitempo, 2014.

OGI, Rodrigo. Crônicas da cidade cinza. São Paulo: Laboratório fantasma. 2011. 1 CD (56 min. 09 seg.).

PAZ, Octavio. Estrella de tres puntas: el surrealismo. In: Excursiones/Incursiones: dominio extranjero. Obras Completas, vol. 2. Ciudad de México: Fondo de Cultura Económica, 1994, p. 203-214.

PEREIRA, Edmilson. Panorama da literatura afro-brasileira. In: Callaloo, College Station v. 18, n. 4, p. 1035-1040, 1995.

SALOMÃO, Waly. Câmara de Ecos. In: Algaravias: câmara de ecos. Rio de Janeiro: Rocco, 2007.

SILVA, P. V. B. da; ROSEMBERG, F. Brasil: lugares de negros e brancos na mídia. In: DIJK, Teun Adrianus van (org.). Racismo e discurso na América Latina. São Paulo: Contexto, 2012, p. 73-117.

TORO, Guillermo Del. O Labirinto do Fauno (El Laberinto del Fauno). ESP/MEX/EUA: Estúdios Picasso, Tequila Gang e Esperanto Filmoj, 2006, DVD. 
WILLER, Cláudio. Prefácio. In: BRETON, André. Manifestos do Surrealismo. Tradução de Luiz Forbes. São Paulo: Brasiliense, 1985, p. 7-22.

Nota do editor:

Artigo submetido para avaliação em: 20 de janeiro de 2021.

Aprovado em sistema duplo cego em: 09 de julho de 2021. 